\title{
CRYSTAL-CHEMICAL CHANGES IN AN OXIDATIVE WEATHERING FRONT IN A GEORGIA KAOLIN DEPOSIT
}

\author{
Paul A. Schroeder ${ }^{1, *}$, Robert J. Pruett ${ }^{2}$ and Nathan D. Melear ${ }^{1}$ \\ ${ }^{1}$ Department of Geology, University of Georgia, Athens, GA 30602-2501, USA \\ ${ }^{2}$ IMERYS, Sandersville, GA 31082, USA
}

\begin{abstract}
The Eocene Huber Formation, exposed in the CFI Hall mine south of Irwinton, in Wilkinson County, Georgia, displays colored zones that are a consequence of an oxidative weathering front. These zones vary from very light gray (gray) to pinkish white (pink) to very pale yellow (cream) (Munsell N8, $5 Y R \quad 8 / 2$ and 2.5 Y $8 / 2$, respectively) with increasing degree of oxidation. A representative sample from each zone was collected and analyzed for its chemical, crystallographic and Raman spectroscopic properties. The comparison of these genetically related samples allowed for a quantitatively accurate assessment of anatase's contribution to the total $\mathrm{TiO}_{2}$ content. All samples contain $\sim 1.5$ wt. $\% \mathrm{TiO}_{2}$. Progressing from gray to pink to cream, anatase contents range from half to nearly all the $\mathrm{TiO}_{2}$. The $a$ lattice parameter for anatase is constant in all three kaolins (3.7916 ̊), suggesting a constant 4.6 mol.\% isomorphous substitution of $\mathrm{Fe}$ for $\mathrm{Ti}$.

Phase characterization and mass-balance considerations of the gray, pink and cream kaolins indicate that ilmenite and pyrite are precursor Ti- and Fe-bearing phases in the gray kaolin that undergo oxidation. Pseudorutile is a proposed intermediate phase resulting from the anodic corrosion of ilmenite. Hematite, goethite and anatase are the dominant end-products via dissolution-precipitation from the reactants pyrite and pseudorutile. The removal of Fe sulfides and organic matter and addition of hematite and goethite causes kaolin colors to change from gray to pink. Oxygen diffusing from groundwater in permeable overlying and underlying formations facilitates a process that probably involves aerobic and anaerobic bacteria that utilize $\mathrm{Fe}$ from pyrite, hematite and goethite. We postulate that the end result is the mobilization of $\mathrm{Fe}$ by siderophores and a kaolin color change from pink to cream.
\end{abstract}

Key Words-Anatase, Crandallite, Hematite, Ilmenite, Kaolinite, Pseudorutile, Rutile, XRD, Raman.

\section{INTRODUCTION}

The chemical and mineralogical properties of kaolin deposits of Georgia, USA, are influenced by numerous pre-depositional and post-depositional biogeochemical events. Hurst and Pickering (1989) have proposed that post-depositional reduction-oxidation (redox) reactions have a significant impact on the economics of kaolin ore, particularly those that are selected for beneficiation and use in paper, polymers and ceramics. Detailed mass balance studies of redox alteration fronts in kaolin deposits are useful because they help us better understand post-depositional biogeochemical reaction mechanisms operating in both time and space. The purpose of this study is to examine the chemical mass balance and mineralogical changes across a redox front within a kaolin deposit. Mineralogical characterization associated with chemical change is essential to understanding the pathways and reaction mechanisms involved during redox processes.

\section{BACKGROUND}

The Georgia-South Carolina kaolin belt contains large reserves of sedimentary-hosted kaolin deposits that

* E-mail address of corresponding author:

schroe@uga.edu

DOI: $10.1346 /$ CCMN.2004.0520207 are often subdivided by texture into "hard" and "soft" types (Hurst and Pickering, 1989). Hard kaolins break with difficulty to show rough, hackly fracture textures and typically have $>70 \%$ by weight, crystals with sizes of $<2 \mu \mathrm{m}$ (Pruett, 2000). Soft kaolins break easily to show smooth, conchoidal fracture textures and typically have coarser crystals with $<70 \%$ of the sizes $<2 \mu \mathrm{m}$. Further subdivision of kaolins is on the basis of color, which is informally referred to as either gray, pink, red or cream. The cause of coloration is related to the minor amounts of various phases. Gray kaolins are colored by $\mathrm{FeS}_{2}$ (pyrite and marcasite), ferrous silicates and kerogen (White et al., 1991). Red kaolins are predominantly colored by hematite and cream kaolins are colored by goethite and anatase.

Schroeder and Shiflet (2000) provided the first quantitative measurement of Ti-bearing phases in a pale yellow (i.e. cream) east Georgia kaolin deposit. Based on quantitative X-ray diffraction (XRD) and chemical techniques, they were able to separate anatase from the total $\mathrm{TiO}_{2}$ content and show that the pale yellow coloration could be ascribed to Fe-substituted anatase. Samples from their study were entirely cream and therefore they could only speculate on the nature of the precursors. Examination of their Figures 2 and 3 reveals that the greatest proportion of anatase and nonanatase $\mathrm{TiO}_{2}$ occurs in the center of the deposits. They ascribed the changes in total $\mathrm{TiO}_{2}$, in part to the 
depositional mechanism of hydraulic sorting of heavy minerals associated with a transgressive depositional sequence. They also propose that post-depositional recrystallization and mass loss of alkali phases could result in a relative increase in anatase concentrations. The relative increase in non-anatase $\mathrm{TiO}_{2}$ towards the center of the deposit suggests that reaction fronts propagate from all sides of a kaolin deposit (i.e. from the 'outside in').

Published studies of actual color (i.e. redox) interfaces in kaolins are limited. Hurst and Pickering (1989) noted that Georgia kaolins are generally gray when covered by $>15 \mathrm{~m}$ of overburden, and partly to entirely oxidized to cream when covered by $<8 \mathrm{~m}$ of overburden. White et al. (1991) observed that both hard and soft gray kaolins adjacent to redox interfaces contained marcasite and a higher total $\mathrm{S}$ content. They suggest that marcasite forms from the diffusion of sulfate derived from adjacent oxidized zones and subsequent sulfate reduction in the gray zone.

\section{MATERIALS AND METHODS}

\section{Geologic setting}

The Lower to Middle Eocene Huber Formation occurs as a hard kaolin in the CFI Hall mine operated by IMERYS south of Irwinton, in Wilkinson County, Georgia. The formation displays colored zones that are evidence for an oxidative weathering front. These zones change from very light gray to pinkish white to very pale yellow (Munsell N8, 5YR 8/2 and 2.5Y 8/2, respectively) with increasing degree of oxidation. These zones are referred to herein as gray, pink and cream kaolins, respectively.

The mine exposure generally displays an upward changing coloration, beginning at the base with $\sim 3 \mathrm{~m}$ of gray kaolin, changing to $\sim 2 \mathrm{~m}$ of pink kaolin, capped by $\sim 3 \mathrm{~m}$ of cream kaolin. The 7 to $15 \mathrm{~m}$ of smectite-rich marine sands and shale of the Barnwell Group overlying the kaolin, exhibit evidence of oxidation by their overall yellow to brown color (Figure 1a). The pink kaolin is consistently between the gray and cream kaolin. The contact between oxidized (pink) and reduced (gray) zone is irregular, however it is laterally persistent through the mine exposure and does not coincide with lithologic boundaries. In some cases, isolated patches of gray kaolin exist with halos of pink and cream kaolin (Figure 1b). A representative sample was selected from each of the three zones as shown in Figure 1b. All samples were collected in a radial trend going from gray to pink to cream.

\section{$X$-ray diffraction, chemical analysis and spectroscopy}

The X-ray diffraction (XRD) analyses were conducted using a Scintag XDS-2000 diffractometer, solidstate detector, and $\mathrm{Cu}$ radiation source. Back-filled pressed sample mounts were made to minimize trans- parency and sample displacement effects, as discussed by Hurst et al. (1997). Quantitative analysis for anatase content was performed using the internal standard method $(\mathrm{ZnO})$ and is thoroughly discussed in Schroeder and Shiflet (2000). The methodology for indexing and unit-cell refinements of the anatase is also described in Schroeder and Shiflet (2000). In brief, samples were digested to remove kaolinite with $5 \mathrm{~N}$ $\mathrm{NaOH}$ using the method of Kampf and Schwertmann (1982) as modified by Singh and Gilkes (1991). Halite was added as an internal standard to the digestion residuum to determine the anatase lattice parameters and mean coherent scattering length according to the Scherrer equation (Klug and Alexander, 1974). The XRD pattern simulation was accomplished using the computer program CrystalDiffract (Palmer, 2003).

Total C was determined using a Micro-Dumas analysis based on transformation of organic matter to gas phase by extremely rapid and complete flash combustion of the sample (Schroeder and Ingall, 1994). Quantification of $\mathrm{Si}, \mathrm{Al}, \mathrm{Fe}, \mathrm{Al}, \mathrm{Ca}, \mathrm{Mg}, \mathrm{K}$ and $\mathrm{Na}$ was accomplished by analyzing fused discs with a
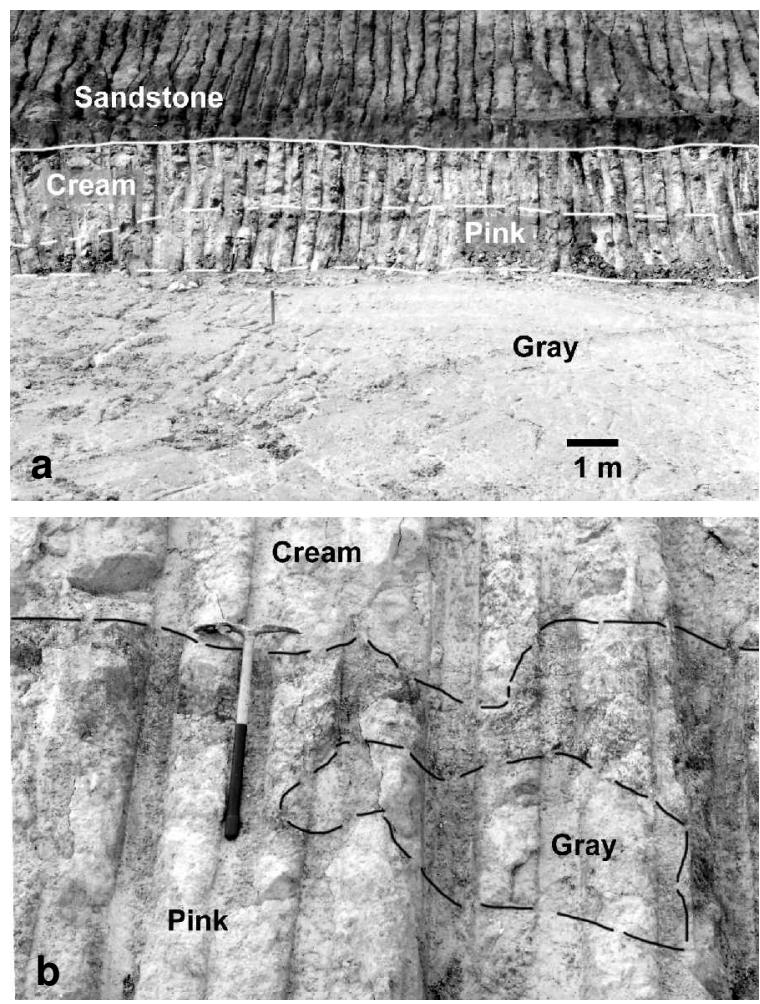

Figure 1. (a) Photograph of the Oconee Group, Lower to Middle Eocene Huber Formation, freshly exposed in CFI Hall mine. Dashed lines separate gray, pink and cream coloration zones. The porous, unconformable overlying Barnwell Group, Clinchfield Sand is seen as the dark-colored stratum. Vertical striations are from the mining equipment. (b) A close-up view from within the CFI Hall mine reveals that oxidation fronts migrate from above, below and laterally. The sequence of gray $\rightarrow$ pink $\rightarrow$ cream is most common. 
Philips PW1480 X-ray fluorescence spectrometer (XRF) equipped with a Sc/Mo dual anode source. Phosphorus was determined colorimetrically from samples wetashed using $\mathrm{HF}$ and $\mathrm{HClO}_{4}$. Extractable $\mathrm{Fe}$ was determined by two different techniques. The first method employed citrate-dithionate-bicarbonate (CDB) as described by Schroeder and Ingall (1994). The second method used $5.8 \mathrm{~N} \mathrm{HCl}$ as described by Schroeder and Pruett (1996). Subsequent to Fe extraction, Fe analysis was determined by atomic absorption.

Transmission electron microscopy (TEM) was carried out at the University of Georgia Center for Advanced Ultrastructural Research. Samples were prepared by applying dilute slurries to Formvar coated copper grids (Shiflet, 1999).

Quantitative Raman spectroscopy was conducted using a Nicolet FT-Raman 950 spectrometer. This spectrometer employs a near-infrared 5 watt multimode Nd-YAG diode laser operating at $1064 \mathrm{~nm}$ with continuous, variable attenuation, capable of delivering power to the sample in the range $0.02-1.2$ watts. Detection is by a Michaelson interferometer and an InGaAs detector. Details for the quantitative methods are discussed in Schroeder et al. (2003).

\section{RESULTS}

\section{Chemistry}

Chemical data for the cream, pink and gray clays from the CFI Hall Mine are presented in Table 1. Replicate analyses reveal precision errors that range from $\pm 0.3 \mathrm{wt} . \%$ for the reported values above $10 \mathrm{wt} . \%$, to $\pm 0.05 \mathrm{wt} . \%$ for reported values above $1 \mathrm{wt} . \%$, and \pm 0.02 wt. $\%$ for the reported values below 1 wt. $\%$. $\mathrm{SiO}_{2}$ and $\mathrm{Al}_{2} \mathrm{O}_{3}$ values are 1 to 2 wt.\% lower than the ideal stoichiometric kaolinite (46.5 wt.\% and $39.5 \mathrm{wt} \%$, respectively). The departures from ideal stoichiometric kaolinite are due to the presence of accessory phases.
The gray clay contains the largest amount of accessory phases. Relative to the cream and pink clay, the gray clay has about twice the $\mathrm{C}$ content, two orders of magnitude more $\mathrm{S}$, slightly more total $\mathrm{Fe}$ and slightly more K. Within analytical uncertainty, $\mathrm{Ti}, \mathrm{Mg}$ and $\mathrm{Na}$ contents are the same. The $\mathrm{Ca}$ is about four times greater in the cream clay. Both XRD and Raman indicate that rutile is a trace component (e.g. Raman band at $448 \mathrm{~cm}^{-1}$ ) and XRD indicates that ilmenite is a trace component. The loss-on-ignition value is largest for the gray clay.

The XRD analysis of the bulk samples (data not shown) confirms that the $\mathrm{Si}, \mathrm{Al}$ and water (LOI) contents are largely attributed to the kaolinite content. The gray clay exhibits a slightly higher Hinckley index (Hinckley, 1963) than the pink and cream clays (Table 1), thus indicating slightly higher populations of larger coherent scattering domains in the gray clay. Overall, the CFI Hall mine series can be characterized as hard clays containing kaolinite with a high degree of crystalline defects relative to other Georgia kaolins.

The higher $\mathrm{S}$ content of the gray clay is attributable to the presence of pyrite, marcasite and, to a lesser extent, organic matter (White et al., 1991). Typical marine organic matter has a $\mathrm{C} / \mathrm{S}$ ratio of $\sim 3$ (Berner and Raiswell, 1984), which suggests that the $\mathrm{S}$ content coming from organic matter is only $\sim 0.03 \mathrm{wt} . \%$. The $\sim 1$ wt. \% higher LOI value of the gray clay matches well with approximate $\sim 1 \mathrm{wt} \% \mathrm{~S}$ content of the same gray clay. If all $\mathrm{S}$ in the gray clay occurs in $\mathrm{FeS}_{2}$, then, upon heating, the $\mathrm{S}$ would be oxidized to $\mathrm{SO}_{2}$. The presence of $\mathrm{Fe}$ sulfides is further supported by the response of each clay to the $\mathrm{HCl}$ and $\mathrm{CDB}$ extractions. Very little $\mathrm{Fe}$ is released from the gray clay by $\mathrm{HCl}$ acid reduction, while CDB treatment releases the greatest amount of $\mathrm{Fe}$ from the gray clay. The presence of reduced $\mathrm{S}$ species, found in CDB solutions, has been shown to release $\mathrm{Fe}$ selectively from fine-grained pyrite (Canfield et al.,

Table 1. Chemical data for Hall mine series. All values are reported as wt.\% unless noted.

\begin{tabular}{|c|c|c|c|c|c|c|c|c|c|c|}
\hline Sample & $\mathrm{SiO}_{2}$ & $\mathrm{Al}_{2} \mathrm{O}_{3}$ & $\mathrm{TiO}_{2}$ & $\mathrm{Fe}_{2} \mathrm{O}_{3}$ & $\mathrm{MgO}$ & $\mathrm{CaO}$ & $\mathrm{Na}_{2} \mathrm{O}$ & $\mathrm{K}_{2} \mathrm{O}$ & $\mathrm{P}_{2} \mathrm{O}_{5}$ & LOI* \\
\hline Cream & 44.7 & 38.9 & 1.45 & 0.55 & 0.041 & 0.132 & 0.039 & 0.096 & 0.031 & 13.7 \\
\hline Pink & 44.6 & 38.5 & 1.50 & 1.20 & 0.043 & 0.039 & 0.037 & 0.102 & 0.048 & 13.9 \\
\hline \multirow[t]{2}{*}{ Gray } & 43.7 & 37.9 & 1.42 & 1.41 & 0.035 & 0.040 & 0.040 & 0.116 & 0.048 & 14.8 \\
\hline & Total C & Total S & $\begin{array}{c}\mathrm{Fe}_{2} \mathrm{O}_{3} \\
\mathrm{HCl} \\
\text { Extract }\end{array}$ & $\begin{array}{c}\mathrm{Fe}_{2} \mathrm{O}_{3} \\
\mathrm{CDB} \\
\text { Extract }\end{array}$ & $\begin{array}{c}\text { XRD } \\
\text { Anatase }^{\S}\end{array}$ & $\begin{array}{c}\text { Raman } \\
\text { Anatase }^{* *}\end{array}$ & $\begin{array}{c}\text { Anatase } \\
\mathrm{Fe}_{2} \mathrm{O}_{3}{ }^{\#}\end{array}$ & $\begin{array}{l}\text { Hinckley } \\
\text { index }\end{array}$ & $\begin{array}{c}\text { Crude } \\
\text { brightness }\end{array}$ & \\
\hline Cream & 0.031 & 0.003 & 0.18 & 0.04 & $1.39(.13)$ & 1.32 & 0.03 & 0.38 & 77 & \\
\hline Pink & 0.044 & 0.009 & 0.71 & 0.05 & $1.02(.09)$ & 0.86 & 0.02 & 0.33 & 68 & \\
\hline Gray & 0.101 & 1.309 & 0.03 & 0.11 & $0.87(.03)$ & 0.59 & 0.01 & 0.46 & 62 & \\
\hline
\end{tabular}

* Loss on ignition. ${ }^{\S} \mathrm{Wt} . \%$ based on XRD and standard addition method. Parenthetic numbers are $1 \sigma$ standard deviation of replicate analyses. ** Wt.\% determined by Raman spectroscopy and standard addition method. \# Based on average mole fraction of Fe isomorphously substituted in anatase using XRD measurements $(a=0.3791 \AA$ ), the curve of Schwertmann et al. (1995), and wt.\% anatase as determined by Raman spectroscopy (Schroeder et al., 2003). 


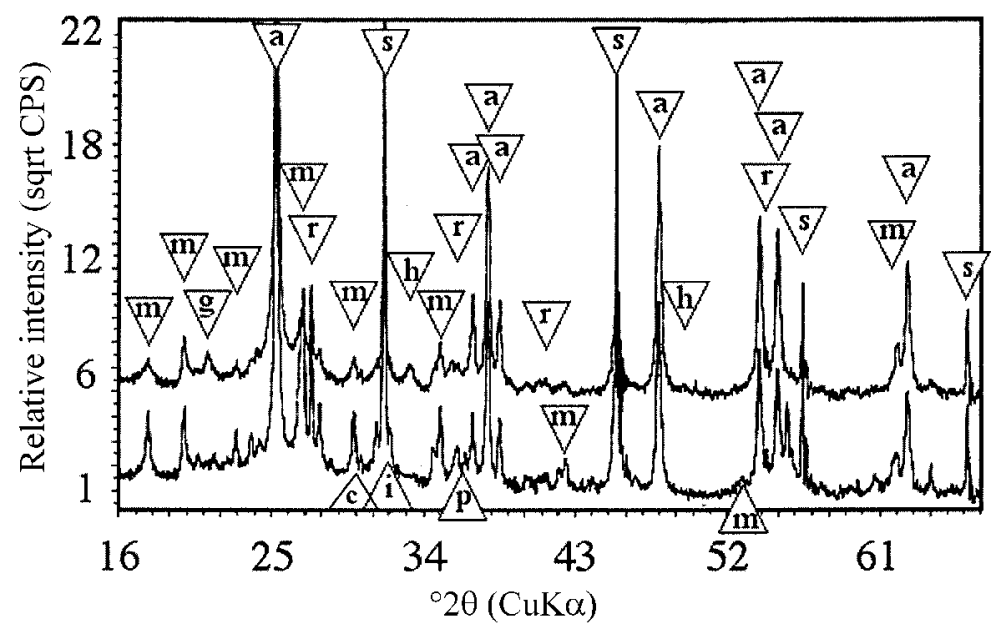

Figure 2. XRD pattern (CuK $\alpha$ stripped) of gray (lower) and pink (upper) clay residue after NaOH digestion. Strong-intensity reflections have been identified and labeled with the following symbols: (a) anatase, (c) crandallite, (g) goethite, (h) hematite, (i) ilmenite, (m) $2 M_{1}$ illite, (p) pseudorutile and (s) halite as an internal standard. Unlabeled peaks are subsidiary reflections of the phases above. Intensities are plotted on a square root of counts per second (CPS) to visually enhance smaller peaks (figure modified from Schroeder et al., 2003).

1992). Reduced S can also release Fe from Fe sulfates that have formed as oxidative products subsequent to sample collection. Evidence for the incipient oxidation of pyrite is supported by the observation in this study that after several days of exposure to air, pyrite in gray kaolin becomes undetectable by XRD.

The higher Fe release response to acid treatment by the pink and cream kaolin shows that more Fe oxide and $\mathrm{Fe}$ oxyhydroxides are present than in the gray kaolin (Table 1). The pink kaolin releases the largest amount of acid-soluble Fe. Analysis by XRD after kaolinite digestion reveals the presence of goethite and hematite (Figure 2). One additional contribution to the total $\mathrm{Fe}$ content is the isomorphous substitution of $\mathrm{Fe}$ for $\mathrm{Ti}$ in anatase and other Ti-bearing phases (Table 1). Latticeparameter measurements of the anatase indicate that $\sim 4.6 \mathrm{~mol} . \% \mathrm{Fe}$ resides in the normal Ti site (Schroeder and Shiflet, 2000; Schwertmann et al., 1995). The residual $\mathrm{Fe}$ content is attributed to $\mathrm{Fe}$ isomorphously substituted into the kaolinite structure.

The $\mathrm{P}$ detected is most likely associated with trace amounts of crandallite, $\mathrm{CaAl}_{3}\left(\mathrm{PO}_{4}\right)_{2}(\mathrm{OH})_{5} \cdot\left(\mathrm{H}_{2} \mathrm{O}\right)$ (detected as a small peak at $30^{\circ} 2 \theta$ in Figure 2). Crandallite group minerals are found as trace constituents in marine sedimentary rocks and weathering profiles associated with the acidic leaching/hydrolysis of silicate and carbonate rocks under both oxidizing and reducing conditions (Weibel, 1998; Mordberg, 1999). In the case of marine sediments, phosphates precipitate within sulfate reducing and methanogenic zones of early diagenesis, whereby phosphate is liberated from Fe/Mn oxyhydroxides during organic matter degradation (Rasmussen et al., 1998). Calcium-bearing minerals in igneous rocks (e.g. plagioclase and apatite in pegmatites; Baldwin et al., 2000) or calcite in carbonate rocks serve as parent sources for the formation of $\mathrm{Ca}$ phosphates.

\section{DISCUSSION}

\section{Titanium mass-balance}

Quantitative measurement of anatase combined with measurement of total $\mathrm{TiO}_{2}$ allows an improved understanding of the non-anatase Ti-bearing components in Georgia kaolin deposits and the fate of coexisting Fe-bearing phases involved with redox reactions. Figure 3 shows the wt.\% of $\mathrm{TiO}_{2}$ and $\mathrm{Fe}_{2} \mathrm{O}_{3}$ and $\mathrm{C}$ in the gray, pink and cream kaolins. The increasing proportion of anatase relative to the non-anatase- $\mathrm{TiO}_{2}$ with increasing extent of weathering provides strong evidence that the anatase is derived from oxidation of Fe-Ti-bearing precursors. The precursors in the gray kaolin are rutile and ilmenite, as shown by XRD and Raman spectroscopy.

The alteration of ilmenite to form leucoxene in strand line deposits of the southeastern US is well described by Force (1991). Leucoxene, however, is a descriptive term that does not identify the exact phases. Portrayal of specific mineral transformation pathways requires

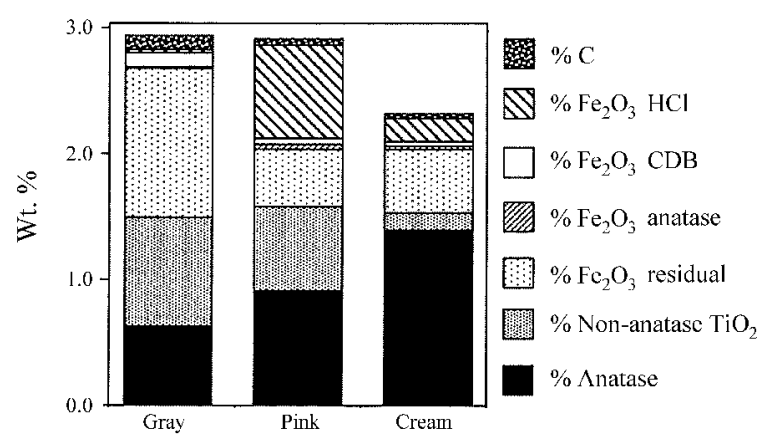

Figure 3. Quantitative summary of $\mathrm{Fe}$, Ti and $\mathrm{C}$ in Hall series samples. All values are plotted as wt.\%. Values were determined by XRF, Raman, extraction and combustion techniques. 
precise knowledge of intermediate phases. Gray and Reid (1975) highlighted the confusion that often results from applying the XRD method to the study of transformation pathways and intermediate alteration phases. The scattering domains of intermediate phases are often extremely small and this results in weak coherent scatter. This is exacerbated by the fact that many of the potential alteration phases have coincident lines. During the oxidative weathering of ilmenite in Australia and Indonesia, Grey and Reid (1975) and Larrett and Spencer (1971) describe a ferrous to ferric transformation pathway that involves progressive removal of ferrous $\mathrm{Fe}$ by leaching with rutile occurring as the residual phase after complete oxidation.

Grey and Reid (1975) describe pseudorutile as an intermediate product with a structure containing local metal ordering resulting from the oxidation of ilmenite. The crystal-chemical structural properties of pseudorutile are developed by the successive growth of cation vacancies that propagate along the [110] direction of ilmenite. This process starts toptactically, with the diffusion of $\mathrm{Fe}^{3+}$ through the structure. No oxygen is lost from the mineral structure during this phase. Ferric $\mathrm{Fe}$ and electrons released by this anodic corrosion process may be facilitated by siderophores which use the electrons in hydroxyl-producing cathodic reactions (Santelli et al., 2001). Ferric Fe and hydroxyl groups bond and occur as incipient goethite (nano?) crystals. Under oxic to dysoxic conditions, the ferrous ions are removed from ilmenite and only ferric ions exist in the pseudorutile structure. Continued removal of $\mathrm{Fe}$ must occur by the removal of structural oxygen. This can only occur through a dissolution process that is possibly further facilitated by siderophores (Cornell and Schwertmann, 1996). The precipitates from this process are anatase and hematite.

This proposed pathway for ilmenite transformation in Georgia kaolin is supported by a detailed examination of the XRD pattern background of the kaolinite-extracted gray kaolin. Figure 4 contains the diffraction pattern of the gray kaolin concentrate. The background is generally thought to be a consequence of Compton scattering effects and diffuse scattering due to disorder (Hurst et al., 1997). Close inspection of the background in Figure 4 reveals a series of broad regions with elevated scattering effects. The solid line below is a calculated pattern derived from a forward modeling approach (i.e. trial and error until a visually optimized solution is found). The calculated pattern is composed of a 98:2 mixture of anatase and pseudorutile. The patterns were calculated using extremely small coherent scatting lengths of $3.5 \mathrm{~nm}$ for both phases (Palmer, 2003). A linear background was added to include Compton scattering. The agreement between the synthetic pattern and the sample background is close enough to support the notion that both phases are present. The coexistence of ilmenite, pseudorutile, rutile and anatase seen in XRD and Raman suggests a transformation pathway similar the one proposed by Grey and Reid (1975).

In gray kaolins of Georgia, in situ oxidation of ferrous ions in ilmenite produces electrons that move through the mineral structure to the surface, whereby the complementing half-cell reaction of oxygen reduction (in pore waters) produces hydroxyl groups. Shelobolina (2000) suggested that this process is promoted in kaolins by aerobic acidophilic bacteria. Barker and Hurst (1992) have documented the presence of bacterial trace fossils in Eocene kaolins of the Huber Formation in Georgia.

The migration of ferric ions into pores enriched with hydroxyls makes favorable the conditions for goethite formation. Goethite crystals found in proximity to the Ti-bearing phase support this idea (see $e . g$. Figure 5 and Hurst et al., 1997), which is further supported by the recent work by Schroeder et al. (2002) who documented goethite in dissolution pits of ilmenite from soils on the Georgia Piedmont. The reaction pathway of ilmenite to this point does not require removal of oxygen from the intermediate forming product pseudorutile. This reaction results in a significant volume reduction (6\%) that stresses the structure (Grey and Reid, 1975). In the presence of siderophore-produced organic acids (Maurice et al., 2000; Shelobolina, 2000), pseudorutile then undergoes complete dissolution with anatase and hematite left as the end-reaction products.

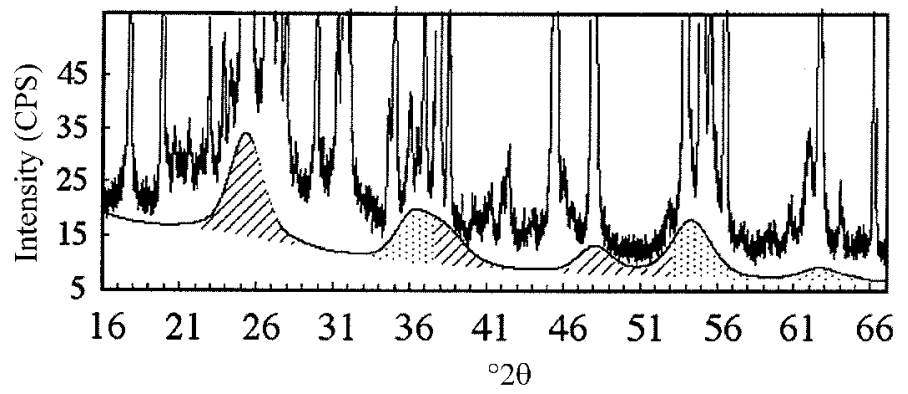

Figure 4. XRD pattern (CuK $\alpha$ radiation) of gray kaolin from the CFI Hall mine series. Solid line below is a calculated XRD pattern for Compton scattering by mixture of anatase and pseudorutile assuming a 98:2 ratio and each with a mean coherent scattering length of $3.5 \mathrm{~nm}(35 \AA)$. The shaded areas represent scatter from anatase (diagonal) and pseudorutile (stippled). 


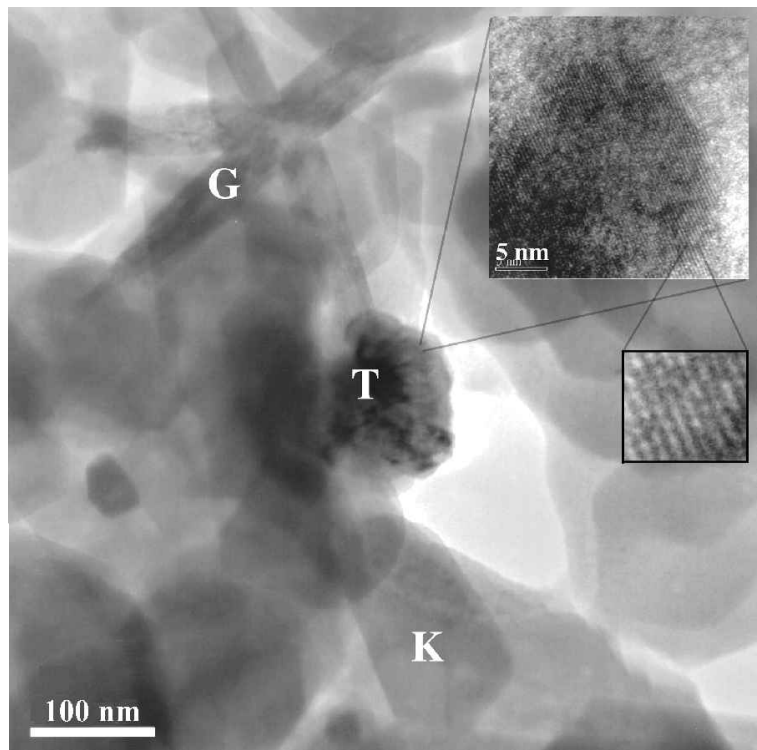

Figure 5. TEM image of CFI Hall mine gray kaolin. $\mathrm{T}=\mathrm{Ti}-$ bearing phase, $\mathrm{G}=$ goethite and $\mathrm{K}=$ kaolinite. The first inset is an enlargement of a nano-crystalline region. The second inset shows lattice fringes with a repeat of $\sim 0.35 \mathrm{~nm}$. Coherent scattering domains appear to range from 2 to $5 \mathrm{~nm}$.

Biotite is another possible precursor responsible for the formation of $\mathrm{Fe}$-Ti-bearing phases. Schroeder and Shiflet (2000) noted a positive correlation between nonanatase $\mathrm{TiO}_{2}$ content and $\mathrm{K}_{2} \mathrm{O}$ content in their study of cream-colored east Georgia kaolins. This correlation is also observed in the CFI Hall mine series (Figure 6). The gray kaolin contains the most $\mathrm{K}$ (Table 1). One possible explanation for the increase in anatase content with increasing degree of oxidation is that Ti-bearing biotite has undergone incongruent dissolution and reprecipitated as kaolinite and anatase. The kaolinitization of biotite has been well documented in a granitic saprolite just to the north of the Fall Line (Schroeder et al., 1997). However, the amount of biotite needed to account for the increased anatase content is far in excess of what is observed in typical crystalline rocks of the Piedmont.

This can be graphically understood by looking at biotite and ideal muscovite stoichiometry for $\mathrm{K}, \mathrm{Fe}$ and

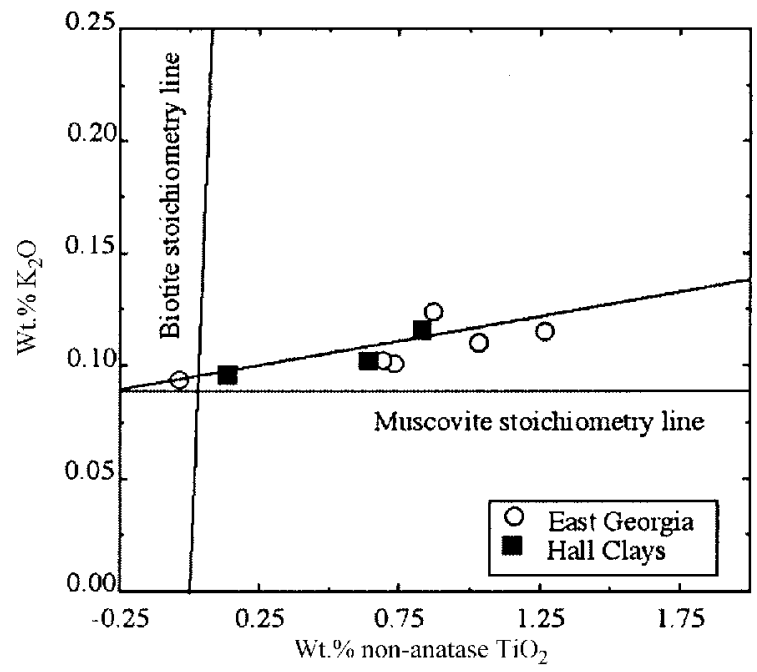

Figure 6. Wt. $\% \mathrm{~K}_{2} \mathrm{O}$ vs. non-anatase $\mathrm{TiO}_{2}$. Squares are data from this study. Circles are data for cream kaolins from east Georgia (Schroeder and Shiflet, 2000). The near-vertical line represents stoichiometry using a typical Georgia Piedmont biotite composition (Schroeder et al., 1997). The horizontal line represents muscovite. The sloping line is a best fit to all the data $\left(\mathrm{r}^{2}=0.78\right)$.

Ti (10:9:1 respectively for biotite using the data of Schroeder et al., 1997 and 10:0:0 for ideal muscovite). The horizontal line plotted on Figure 6 represents a maximum amount of $\mathrm{K}$ assuming all $\mathrm{K}$ is in ideal muscovite. If the additional $\mathrm{TiO}_{2}$ found in the pink and cream kaolins came from incongruent biotite dissolution, then the change in non-anatase $\mathrm{TiO}_{2}$ would be expected to follow the biotite line. The line assumes that $\mathrm{K}$ is conservatively retained. The idea that $\mathrm{K}$ released by the dissolution of biotite is locally retained is untenable because $\mathrm{K}$ is mobilized and removed by the groundwater.

Analysis by XRD shows that 2:1 dioctahedral mica (degraded muscovite or illite) is the dominant mica found in the residual fraction of the kaolins (Figure 2). Therefore, differences in total illite content alone could explain the $\mathrm{K}$ variations in Figure 6. The question remains as to why does non-anatase $\mathrm{TiO}_{2}$ co-vary with $\mathrm{K}_{2} \mathrm{O}$ ?

Table 2. Number of atoms per unit mass of kaolin partitioned into operationally defined phases. Values derived from wt.\% in Table 1 and relevant atomic and formula weights. Units are in $\mu \mathrm{mol} / \mathrm{g}$.

\begin{tabular}{|c|c|c|c|c|c|c|c|c|}
\hline Sample & $\begin{array}{c}\text { Organic } \\
\mathrm{C}\end{array}$ & $\begin{array}{c}\text { Anatase } \\
\mathrm{Ti}\end{array}$ & $\begin{array}{c}\text { Non- } \\
\text { anatase } \\
{ }^{\star} \mathrm{Ti}\end{array}$ & $\begin{array}{c}\text { Hematite } \\
\text { goethite } \\
\text { *Fe }\end{array}$ & $\begin{array}{c}\text { Anatase } \\
{ }^{\#} \mathrm{Fe}\end{array}$ & $\begin{array}{c}\text { Iron } \\
\text { sulfide } \\
{ }_{\S} \mathrm{Fe}\end{array}$ & $\begin{array}{c}\text { Iron } \\
\text { sulfide } \\
{ }^{ \pm} \mathrm{Fe}\end{array}$ & $\begin{array}{c}\text { Kaolinite } \\
* * \mathrm{Fe}\end{array}$ \\
\hline Cream & 2.6 & 16.5 & 1.6 & 2.3 & 0.4 & 0.0 & 0.0 & 4.3 \\
\hline Pink & 3.7 & 10.8 & 8.0 & 8.9 & 0.3 & 0.1 & 1.6 & 4.3 \\
\hline Gray & 8.4 & 7.4 & 10.4 & 0.4 & 0.1 & 20.5 & 12.9 & 4.3 \\
\hline
\end{tabular}

$\$$ Determined by the difference between the total number of $\mathrm{Ti}$ atoms and anatase $\mathrm{Ti}$ atoms. $*$ Determined by total HCl-extractable Fe. "Based on mole fraction of Fe in anatase from XRD data. ${ }^{\S}$ Determined from $\mathrm{S}$ content and assumed $\mathrm{FeS}_{2}$ stoichiometery. ${ }^{ \pm}$Based on difference between total $\mathrm{Fe}$ and the sum of all other components. ** Residual from difference between total $\mathrm{Fe}$ and hematite, goethite and anatase Fe in cream clay. 
One can assess the amount of biotite precursor needed to form non-anatase $\mathrm{TiO}_{2}$ using the mass balance of Ti. Approximately $10 \mu$ moles of non-anatase-Ti per gram of kaolin are transferred to anatase-Ti, going from gray to cream kaolin (Table 2). If all $10 \mu$ moles are derived from biotite, then an initial pre-weathering concentration of $\sim 100 \mu$ moles of biotite per gram of kaolin is required. The difference in $\mathrm{K}$ between the gray and cream kaolin is 4 moles, which would imply 96 moles of $\mathrm{K}$ mass loss per gram of kaolin. $100 \mu$ moles of biotite per gram sample is $\sim 4.6 \mathrm{wt} . \%$. Although this is within the range of biotite concentrations available in unweathered Piedmont crystalline rocks (Schroeder et al., 2000), this amount of biotite is not detected in the gray kaolin. Biotite is known to weather quite rapidly in the Piedmont (Schroeder et al., 1997), therefore it seems less likely that non-anatase Ti is coming from biotite. To know the exact source of $\mathrm{Ti}$ (e.g. ilmenite $v s$. biotite) is still difficult at this point in time.

One possible test to discriminate is to utilize the trace-element abundance in anatase. Pruett et al. (1996) noted that $\mathrm{Cr}_{2} \mathrm{O}_{3}, \mathrm{ZrO}_{2}$ and $\mathrm{Nb}_{2} \mathrm{O}_{3}$ concentrations in anatase from the Georgia kaolin belt range from 0 to 1 wt.\%. These trace elements are known to be elevated in micas from anorogenic pegmatite suites (Černý and Burt, 1984). They also behave in a chemically similar fashion to Ti under earth-surface conditions (Railsback, 2001). Both biotite and rutile are known to incorporate these elements, though their partitioning is expected to be different. A study of trace-element ratios in primary and secondary $\mathrm{Ti}$ phases would perhaps lead to new insights.

\section{Iron mass-balance}

Pink kaolins have more hematite than the gray and cream kaolins. Table 2 shows that for the Hall series, up to $17 \mu$ moles of Fe per gram of kaolin can come from the oxidation of pyrite and/or marcasite. This value is the average of (1) the total $\mathrm{S}$ content assuming a pyrite stoichiometry, and (2) from an assessment of residual $\mathrm{Fe}$ atoms per gram of kaolin after partitioning $\mathrm{Fe}$ to hematite, goethite, anatase and kaolinite. The mass of $\mathrm{Fe}$ from hematite and goethite is based on the total $\mathrm{Fe}$ extracted by $\mathrm{HCl}$. The $\mathrm{Fe}$ from anatase comes from Raman and XRD data. The Fe in the kaolinite structure was determined from the cream kaolin via the difference between total $\mathrm{Fe}$ and that partitioned into $\mathrm{HCl}$ and anatase. The small differences in order/disorder characteristics amongst the kaolins (Table 1) suggest that $\mathrm{Fe}$ in kaolinite for all three samples is similar. This assessment amounts to $\sim 4$ moles of Fe per gram of kaolin from kaolinite.

Our data imply that during the initial phase of oxidation (gray to pink), at least half of the Fe atoms are made soluble and removed. The other half resides in $\mathrm{Fe}$ oxides (Table 2). This is presumably achieved by the combined action of Fe-chelating siderophores and slowly infiltrating groundwaters as proposed by Hurst and Pickering (1997) and Shelobolina (2000). The greater solubility of hematite, relative to goethite under the ambient geochemical conditions further leads to the dissolution of hematite and subsequent migration through the groundwater system. This is supported by the observation that the cream kaolin has three times fewer $\mu$ moles of $\mathrm{Fe}$ per gram of kaolin than the pink kaolin.

\section{Phosphorus mineralization}

The occurrence of crandallite in the CFI Hall mine and in other Tertiary Coastal Plain sediments (Seaman et al., 1997) has several possible modes of origin. The presence of framboidal pyrite in the gray clays indicates that sulfate reduction was occurring at the time of sediment deposition, with the source of sulfate most likely marine-influenced waters. Anoxic conditions at the time of deposition increase the likelihood of an early diagenetic origin for the phosphate phase. Aluminumphosphates, in the form of lazulite $\left(\mathrm{MgAl}_{2}\left(\mathrm{PO}_{4}\right)_{2}(\mathrm{OH})_{2}\right)$ and variscite $\left(\mathrm{AlPO}_{4} \cdot 2\left(\mathrm{H}_{2} \mathrm{O}\right)\right)$ have been described by Schroeder (1999) in the meta-pyroclastic sequences to the north in the Carolina Slate Belt within the Piedmont. Comparisons of unweathered and weathered lazulite indicate that variscite (with a crandallite component) is currently forming in situ (Schroeder, 1999) in the saprolite. However, the extremely limited aerial extent of the variscite-bearing rocks in the up-dip Carolina Slate Belt puts the likelihood of the Piedmont as a source of crandallite at very small.

This would suggest that crandallite in Georgia kaolins owes its origins to an initial early diagenetic phase of phosphate formation and subsequent dissolution and precipitation to form crandallite. A nearby source of Ca for crandallite formation in the CFI Hall mine clays is dissolution of the regionally thin lenses of overlying carbonate found in the Eocene Clinchfield Sand. Dissolution of plagioclase grains both within and in overlying formations and the release of $\mathrm{Ca}$ from the smectite in the Twiggs Clay Formation offer additional sources of $\mathrm{Ca}$. Crandallite formation in Missouri refractory clays has been similarly proposed by Hall et al. (1997).

\section{Genesis of the kaolin deposit}

Theories of the origin of Georgia kaolins place different emphasis on the degree of paleo-Piedmont weathering that created sediment that formed kaolin deposits versus the degree of sediment diagenesis and saprolitization that have modified kaolin deposits (Dombrowski, 1993; Hurst and Pickering, 1997). A test for these theories can be envisioned using the results of this study by assuming that $90 \%$ anatase relative to total titania in the cream clay represents an end-point for the titania-weathering pathway. The remaining $10 \%$ of 
titania are assumed to be in non-labile phases such as rutile. Based on the anatase to non-anatase titania ratios in Figure 3, $\sim 50 \%$ of the phase transition is associated with the psuedorutile to anatase weathering front at the CFI Hall mine. The initial $50 \%$ anatase (relative to titania in the gray clay) could be assumed to represent the maximum alteration that occurred during paleoPiedmont weathering and sediment transport. This is a maximum estimate because the crystal chemistry of the non-anatase titania is poorly constrained. It is also noted that no major difference in kaolinite crystal chemistry is observed across this weathering front. Our observations suggest that kaolinite recrystallization and ilmenite alteration occur at different times. An outcrop with a kaolinite crystallinity gradient would serve to address the relative roles of minerals in the complete $\mathrm{Fe}-\mathrm{Ti}-\mathrm{Al}$ $\mathrm{Si}-\mathrm{O}-\mathrm{H}$ system.

The lack of evidence for anatase as a byproduct from biotite alteration across the weathering front is consistent with the idea that kaolinitization of biotite occurred in the sediment source areas. If the assumption is made that anatase in Georgia kaolins is predominantly a weathering product of biotite, the incompatible element ratios of anatase and biotite should mirror each other. Few published data are available to support this notion. It is interesting to note that the $\mathrm{Ti} / \mathrm{Nb}$ and $\mathrm{Ti} / \mathrm{Zr}$ ratios in anatase analyzed from Georgia kaolins and saprolites (Pruett, 1996) are similar to those reported for crystalline basement-derived biotite by Viswanathan (1973). This assumption of a biotite precursor for titania is based on the belief that weathered ilmenite will segregate with other heavy minerals to the sand and silt-sized fractions during sediment transport, while fine, weathered mica and associated titania will fractionate with the kaolinite.

The CFI Hall mine oxidation study illustrates the potential for use of titania phases to describe the genesis pathways for Georgia kaolin deposits. Further traceelement studies of biotite, ilmenite and anatase are needed to validate this approach. This should lead to an improved understanding of how biotite and ilmenite in rocks of the Georgia Piedmont alter in terms of phase transformations, paragenetic sequences, conservation of trace elements and mineral grain specific trace element ratios. The relative abundance and chemistry of titania minerals contained in kaolins should also help further describe the formation pathways in relatively pure kaolin deposits.

\section{CONCLUSIONS}

The study of an oxidation front propagating through a Georgia kaolin deposit (seen as going from gray to pink to cream) indicates the presence of $\mathrm{Ti}$ - and Fe-bearing phases and their reaction products. Transformation pathways for $\mathrm{Ti}$ - and Fe-bearing precursors are constrained by stoichiometric mass-balancing of closely spaced gray, pink and cream kaolins. Ilmenite was most likely deposited as the most abundant Ti-bearing detrital phase. Pyrite and crandallite formed under reducing early diagenetic conditions. Subsequent to dysoxic lithification and kaolinite crystallization (Hurst and Pickering, 1997), uplift and landscape denudation, kaolin beds were brought into proximity of the surface and became influenced by the diffusion of oxygenbearing groundwaters flowing through permeable overlying Barnwell Group.

Oxidation of ilmenite first proceeds via anodic electrochemical corrosion and results in the formation of pseudorutile (Grey and Reid, 1975). The $\mathrm{Fe}^{3+}$ that diffuses to structural spaces reacts with hydroxyl groups, produced by water-oxygen cathodic reactions to form goethite. A dissolution precipitation mechanism then operates in response to the volumetric changes and stresses associated with pseudorutile formation. Hematite and anatase are products that are manifested in pink kaolins. Contemporaneous with ilmenite oxidation, pyrite oxidizes to produce goethite and hematite. Marcasite forms from the incursion of sulfate derived from adjacent oxidized zones and subsequent bacterial reduction to sulfide in the gray zone as proposed by White et al. (1991). Biotite is kaolinitized with anatase and goethite additionally forming as secondary phases.

Persistent diffusion of oxygenated groundwater into the kaolin beds from permeable overlying and underlying beds results in mass transfer of $\mathrm{Fe}$ out of the kaolin beds. A possible mechanism for this process involves aerobic bacteria (e.g. Pseudomonas mendocina), which acquire Fe from hematite and goethite under Fe-limited conditions (Hersman et al., 1995; Maurice et al., 2000; Shelobolina, 2000). The products of these processes are cream kaolins that have lower total Fe contents.

\section{ACKNOWLEDGMENTS}

This work was supported by a research contract between the University of Georgia Research Foundation and English China Clay International, (now IMERYS Pigments and Additive Group). The XRD data collection was made possible by a grant to the senior author from the National Science Foundation Instrument Facilities Program (EAR-9911501). John Shields assisted with the TEM work. Stephanie Meyers and Doug Hunter assisted with the Raman Spectroscopy. The review by Ray Ferrell improved the manuscript.

\section{REFERENCES}

Baldwin, J.R., Hill, P.G., von Knorring, O. and Oliver, G.J.H. (2000) Exotic aluminium phosphates, natromontebrasite, brazilianite, goyazite, gorceixite and crandallite from rareelement pegmatites in Namibia. Mineralogical Magazine, 64, 1147-1164.

Barker, W.W. and Hurst, V.J. (1992) Bacterial trace fossils in Eocene kaolin of the Huber Formation of Georgia: Phylloderma microsphaerodes, $\mathrm{n}$. ichnogen., $\mathrm{n}$ ichnosp. Ichnos, 2, 55-60.

Berner, R.A. and Raiswell, R. (1984) C/S method for distinguishing freshwater from marine sedimentary rocks. Geology, 12, 365-368. 
Canfield, D.E., Raiswell, R. and Bottrell, S. (1992) The reactivity of sedimentary iron minerals toward sulfide. American Journal of Science, 292, 659-683.

Černý, P. and Burt, D.M. (1984) Paragenesis, crystallochemical characteristics and geochemical evolution of micas in pegmatites. Pp. 257-298 in: Micas (S.W. Bailey, editor). Reviews in Mineralogy, 13. Mineralogical Society of America, Washington, D.C.

Cornell, R.M. and Schwertmann, U. (1996) The Iron Oxides: Structure, Properties, Reactions, Occurrences and Uses. $\mathrm{VCH}$ Velagsgesellschaft, $\mathrm{mbH}$, Weinheim, Germany, $573 \mathrm{pp}$.

Dombrowski, T. (1993) Theories of origin for the Georgia kaolins: A review. Pp. 75-97 in: Kaolin Genesis and Utilization (H.H. Murray, W. Bundy and C. Harvey, editors). Special Publication no. 1, The Clay Minerals Society, Boulder, Colorado.

Force, E.R. (1991) Geology of titanium deposits. Geological Society of America Special Paper 259. Geological Society of America, Boulder, Colorado, $112 \mathrm{pp}$.

Grey, I.E. and Reid, A.F. (1975) The structure of pseudorutile and its role in the natural alteration of ilmenite. American Mineralogist, 60, 898-906.

Hall, R.B., Foord, E.E., Keller, D.J. and Keller, W.D. (1997) Phosphates in some Missouri refractory clays. Clays and Clay Minerals, 45, 353-364.

Hersman, L., Lloyd, T. and Sposito, G. (1995) Siderophorepromoted dissolution of hematite. Geochimica et Cosmochimica Acta, 59, 327-3330.

Hinckley, D.N. (1963) Variability in "crystallinity" values among the kaolin deposits of the Coastal Plain of Georgia and South Carolina. Clays and Clay Minerals, 11, 229-235.

Hurst, V.J. and Pickering, S. (1989) Cretaceous-Tertiary strata and kaolin deposits in the inner Coastal Plain of Georgia. Pp. 1-22 in: Upper Cretaceous and Cenozoic Geology of the Southeastern Atlantic Coastal Plain, Field Trip Guidebook T172. 28 ${ }^{\text {th }}$ International Geological Congress, American Geophysical Union, Washington, D.C.

Hurst, V.J. and Pickering, S.M. (1997) Origin and classification of coastal-plain kaolins, southeastern USA, and the role of groundwater and microbial action. Clays and Clay Minerals, 45, 274-285.

Hurst, V.J., Schroeder, P.A. and Styron, R.W. (1997) Accurate quantification of quartz and other phases by powder X-ray diffractometry. Analytica Chimica Acta, 337, 233-252.

Kampf, N. and Schwertmann, U. (1982) Quantitative determination of goethite and hematite in kaolinitic soils by X-ray diffraction. Clay Minerals, 17, 359-363.

Klug, H. P. and Alexander, L.E. (1974) X-ray diffraction Procedures for Polycrystalline and Amorphous Materials. John Wiley \& Sons, New York, 966 pp.

Larrett, M.J.W. and Spencer, W.G. (1971) Contributions to Australasian Mineralogy, 3. "Pseudorutile" from South Neptune Island, South Australia. Amdel Bulletin, 12, 74-80.

Maurice, P.A., Lee, Y.J. and Hersman, L.E. (2000) Dissolution of Al-substituted goethites by an aerobic Pseudomonas mendocina var. bacteria. Geochimica et Cosmochimica Acta, 68, 1363-1374.

Mordberg, L.E. (1999) Geochemical evolution of a Devonian diapore-crandallite-svanbergite-bearing weathering profile in the Middle Timan, Russia. Journal of Geochemical Exploration, 66, 353-361.

Palmer, D.C. (2003) CrytallDifract v. 4.0.2 - A program to calculate powder $X$-ray diffraction patterns from crystallographic data. CrystalMaker Software. P.O. Box 183, Bicester, Oxfordshire OX26 3TA, UK.

Pruett, R.J. (2000) Georgia kaolin: Development of a leading industrial mineral. Mining Engineering, 52, 21-27.

Pruett, R.J., Yuan, J., Keller, P. and Bradley, J. (1996) Trace element chemistry of anatase in Georgia kaolins. Annual Meeting of the Clay Minerals Society. Gatlinburg, Tennessee. Abstracts with Program. p. 133.

Railsback, B. (2001) An earth scientist's periodic table of the elements and their ions. Earth System Processes - Global Meeting, Edinburgh, Scotland. Abstracts with Program. http://www.gly.uga.edu/railsback/PT.html

Rassmussen, B., Buick, R. and Taylor, W.R. (1998) Removal of oceanic REE by authigenic precipitation of phosphatic minerals. Earth and Planetary Science Letters, 164, $135-149$.

Santelli, C.M., Welch, S.A., Westrich, H.R. and Banfield, J.F. (2001) The effect of Fe-oxidizing bacteria on Fe-silicate mineral dissolution. Chemical Geology, 180, 99-115.

Schroeder, P.A. (1999) Common minerals of Graves Mountain, Georgia. Pp. 12-32 in: Graves Mountains, Georgia: Mineralogy, Economic geology and environmental problems. Field guide for the Southeastern section Geological Society of America Meeting, (Dave Wenner, editor). University of Georgia Department of Geology, Athens, Georgia.

Schroeder, P.A. and Ingall, E.D. (1994) A method for the determination of nitrogen in clays, with application to the burial diagenesis of shales. Journal of Sedimentary Research, A64, 694-697.

Schroeder, P.A. and Pruett, R. (1996) Iron ordering in kaolinites: Insights from ${ }^{29} \mathrm{Si}$ and ${ }^{27} \mathrm{Al}$ NMR spectroscopy. American Mineralogist, 81, 26-38.

Schroeder, P.A. and Shiflet, J. (2000) Ti-bearing phases in an east Georgia kaolin deposit. Clays and Clay Minerals, 48, $151-158$.

Schroeder, P.A., Kim, J.G. and Melear, N.D. (1997) Mineralogical and textural criteria for recognizing remnant Cenozoic deposits on the Piedmont: Evidence from Sparta and Greene County, Georgia, U.S.A. Sedimentary Geology, 108, $195-206$

Schroeder, P.A., Melear, N.D., West, L.T. and Hamilton, D.A (2000) Meta-gabbro weathering in the Georgia Piedmont, USA: Implications for global silicate weathering rates. Chemical Geology, 163, 235-245.

Schroeder, P.A., Le Govlan, J.J. and Roden, M.D. (2002) Weathering of ilmenite from granite and chlorite schist in the Georgia Piedmont, USA. American Mineralogist, 87, $1616-1625$

Schroeder, P.A., Melear, N.D. and Pruett, R.J. (2003) Quantitative analysis of anatase in Georgia kaolins using Raman spectroscopy. Applied Clay Science, 23, 299-308.

Schwertmann, U., Friedl, J., Pfab, G. and Gehring, A.U. (1995) Iron substitution in soil and synthetic anatase. Clays and Clay Minerals, 43, 599-606.

Seaman, J.C., Bertsch, P.M., Strom, R.N. (1997) Characterization of colloids mobilized from southeastern coastal plain sediments. Environmental Science and Technology, 31, 2782-2790.

Shelobolina, E. (2000) Role of microorganism in development of commercial grade kaolins. Pp. 45-56 in: Geology of the Commercial Kaolin Mining District of Central and Eastern Georgia (J. Elzea Kogel, S.M. Pickering Jr., E. Shelobolina, J. Yuan, T.M. Chowns and D.M. Avant, editors). Georgia Geological Society Guidebooks, Volume 20, Atlanta, Georgia.

Shiflet, J.E. (1999) Ti-bearing phases in an east-Georgia kaolin deposit. M.S. thesis, University of Georgia, Department of Geology, Athens, Georgia, 78 pp.

Singh, B. and Gilkes, R. J. (1991) Concentration of iron oxides from soil clays by $5 \mathrm{M} \mathrm{NaOH}$ treatment; the complete removal of sodalite and kaolin. Clay Minerals, 26, 463-472.

Viswanathan, S. (1973) A geochemical study of niobium distribution and of $\mathrm{Nb}-\mathrm{Ti}$ and $\mathrm{Nb}-\mathrm{Zr}$ relations in some 
phyllosilicates. Current Science, 42, 524-527.

Weibel, R. (1998) Diagenesis in oxidising and locally reducing conditions - an example from the Triassic Skagarrek Formation Denmark. Sedimentary Geology, 25, 259-276. White, N.G., Dixon, J.B., Weaver, R.M. and Kunkle, A.C.
(1991) Genesis and morphology of iron sulfides in gray kaolins. Clays and Clay Minerals, 39, 70-76.

(Received 3 March 2003; revised 13 October 2003; Ms. 769; A.E. Ray E. Ferrell, Jr.) 